\title{
RESEARCH ETHICS: AN INVESTIGATION INTO WHY SCHOOL LEADERS AGREE OR REFUSE TO PARTICIPATE IN EDUCATIONAL RESEARCH
}

Lisbeth M. Brevik

University of Oslo, Oslo, Norway

E-mail: I.m.brevik@ils.uio.no

\begin{abstract}
The present qualitative study investigates the reasons given by 236 Norwegian upper secondary school leaders when they either accepted or refused to take part in a research project. The analysis shows that those who agreed to participate gave two main reasons, while the range of reasons among those who refused was more diverse. Moreover, when making their decisions the school leaders considered the consequences for their schools and their teachers, and to some extent, their students. These findings are discussed in relation to consequence ethics and value judgments, in the hope of contributing to a renewed perspective on research ethics. There is a tendency to consider research ethics a matter of how researchers should treat their participants to safeguard the participants' interests. However, the findings of the present study suggest that it is equally important to understand the participants' perspectives, which will in turn help researchers provide the information needed to better inform, and hopefully recruit participants for research projects.
\end{abstract}

Key words: accountability, consequence ethics, professional development, reading, research ethics.

\section{Introduction}

What does ethical consideration in research mean in practice? Hammersley and Traianou (2012a, p. 3) point out that "researchers depend upon being allowed access to data, and this may involve people cooperating in various ways". Given this, how can people who participate in research projects be protected? Modern day protection of research participants started with the Nuremberg Code (1947), in a code of ethics which addresses the basic principles of the ethical conduct of research, including the principle of voluntary consent. Heath, Charles, Crow and Wiles $(2004$, p. 1) point out that "gaining informed voluntary consent from people involved in research is generally regarded as central to ethical research practice". Voluntary consent ideally means that a researcher does not pressure anyone into agreeing to participate in a research project (Silverman, 2011), but rather seeks to obtain participants' voluntary consent (Creswell, 2013; Hesse-Biber \& Leavy, 2011).

Although researchers make an effort to understand and explain participants' reasons for consenting to participate in research, less attention has been given to the participants' own perspectives. Indeed, if potential participants refuse to participate in a research project, a researcher might consider this a failure on his or her part (Hesse-Biber \& Leavy, 2011), rather than considering the reasons for non-participation. Unless explicitly asking for explanations, little is known about the participants' own reasons for agreeing or refusing to participate in research, and whether these reasons can be understood in the light of ethical reasoning.

The ethical regulation of educational research has increased during the last sixty years. However, in his article, "Against the ethicists: on the evils of ethical regulation", Hammersley (2009, p. 212) argues the following: 
Lisbeth M. BREVIK. Research Ethics: An Investigation into Why School Leaders Agree or Refuse to Participate in Educational Research

\author{
PROBLEMS \\ OF EDUCATION \\ IN THE $21^{\text {st }}$ CENTURY

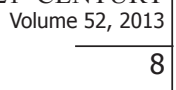

\begin{abstract}
It is important to recognize that [research ethics committees'] regulatory role involves a claim to considerable authority. And this authority is based, presumably, on an appeal to expertise. In effect, ethics committees claim the ability to determine what is and is not, would and would not be, ethical in any particular research project, and to make better judgments about this than the researcher(s) involved in the project being regulated. (p. 212)
\end{abstract}

Against this bureaucratic command, he points out that ethical committees' main function is to encourage researchers to reflect on ethical aspects of their work, and he argues that "[t] hey could, quite legitimately and usefully: (1) offer advice, (2) provides a forum in which ethical principles and their application can be discussed and (3) initiate discussion about problem cases" (Hammersley 2009, p. 220). What is involved in the regulations and application of ethical principles concerns the protection of participants. In Norway, the Guidelines for Research Ethics in the Social Sciences, Law and the Humanities, and the Personal Data Act now make the ethical regulation of research a requirement. Therefore, most research projects in Norway must notify the Data Protection Official for Research (NSD).

Participation in a research project might be considered the right thing to do if it produces more overall good than non-participation. The decision about whether or not a school should participate must be fully evaluated in each case and the school leaders must consider the duty and the consequences of participation before they can make an ethically sound choice. In this study, school leaders refer to the principal or other person in the school administration appointed by the principal; i.e. assistant principal or department head.

The challenge for a school leader is how to determine what a school's obligation is in such a situation, as well as which consequences will produce "more overall good" than the alternative. Another challenge is to decide for whom participation is good: the students, the teachers, the school, the researcher, or the school authorities? Ryen (2011) and Homan (2001) point out that some people hold positions as gatekeepers where they are able to provide a researcher access to a group that is willing to consent in that particular context. If teachers perceive the power relation between themselves and their leader as uneven, and if they feel that they have to consent to what their school leader proposes, it might be problematic when the school leader grants participation in a project. This is because the democratic right to freedom and self-determination should include the right to choose whether or not to take part in a research project (Busher \& James, 2012). A third challenge is whether these potential participants have received relevant information about what participation entails (Fowler, 2009) to ensure informed consent on behalf of the school, the teachers or the students. In these cases, the reasoning about participation or non-participation is in itself an ethical discussion that will involve multiple viewpoints (Ryen, 2011).

The rationale for this study is the increased attention given to the idea of informed voluntary consent, with the apparent paradox that while a researcher is obliged to provide information, the same researcher might not know what information is relevant to provide. A researcher's observation of relevant information is shaped by his or her prior knowledge of what constitutes relevant information for potential informants. Further, a researcher's observation of ethical guidelines might be shaped by prior knowledge of participants' ethical reasoning in this process. The decision to accept or refuse participation might also be based on school owners' increased demand for accountability from school leaders (Elstad, Christophersen \& Turmo, 2012; Propper \& Wilson, 2003). In other words, educational researchers should be interested in why schools accept or refuse to participate in research projects. 
Lisbeth M. BREVIK. Research Ethics: An Investigation into Why School Leaders Agree or Refuse to Participate in Educational Research

Against this background, the following main research question is addressed: What reasons do school leaders give when agreeing or refusing to participate in educational research? Based on this overall research question, the following subsidiary questions are explored:

(1) What reasons do school leaders give for participating or not participating?

(2) Do they argue from the perspective of the students, the teachers or the school?

(3) How explicit are their answers in terms of ethical reasoning?

This study can provide data about ethical reasoning among informants in educational research. This might be of particular value for researchers when deciding what kind of information is relevant when recruiting potential informants. A high response rate is necessary to avoid threats against the external validity (Cook \& Campbell, 1979). Having provided a brief overview of this study, its context and research questions, the next section turns to some ethical theories that relate to the informants' reasoning in relation to the process of giving or declining to give consent to participate in this research project.

\section{Ethical Reasoning}

Ethics involves making normative judgments according to a standard for what is right and good. The term ethics can mean one's customs, habits, character or disposition. Many professions, including educational researchers, have their own codes of ethics. Researchers need to consider ethical issues as well as how to carry out their research (Fowler, 2009). As researchers, we need to ask ourselves what responsibility we have toward participants in a research project, such as whether they have enough information to give informed consent (Hesse-Biber \& Leavy, 2011). The research community has also emphasized the importance of normative and undisputed rules as guidelines in research, with informed voluntary consent being the hallmark of ethical conduct (Creswell, 2013; Hammersley, 2009; Ragin \& Amoroso, 2011). However, there seems to be a lack of research focusing on respondents' reasoning for choosing to participate or not participate in research.

Building on the conceptualizations of classical ethical theories of consequence (Bentham, 1789, 2005; Mill, 1863) and duty (Kant, 1785), ethical reasoning might be understood as reasoning about right and wrong human conduct. There is a clear tension between these two approaches, which reflects a philosophical conflict between two meta-ethical positions (Hammersley, 2009). Whereas consequence ethics consider the potential effects of one's actions, for example in terms of cost/harm and benefit, duty ethics are concerned with duties or rights, where right and wrong human conduct are considered in terms of what is inherently good or bad (Vestøl, 2005). An example is the ethical reasoning that school leaders engage in when they argue for or against participating in a research project, based on ethics of actions or principles. Ethical reasoning can also be conceptualized as a tool for school leaders to reflect on and evaluate their participation in research. Following this line of thought, school leaders' reasons involve consequences or effects, and duties or rights for their schools.

Consequence ethics rely on utilitarian reasoning to predict the best possible outcome of an act. The act is to be evaluated by its utility, meaning the intrinsic value of the act and its consequences (West, 2013). In other words, utilitarianism evaluates an act in terms of the effects it produces; it considers which choice will lead to the best results and consequently produce the maximum common best. Mill $(1863)$ and Bentham $(1789,2005)$ interpreted utility in terms of the "greatest happiness principle", meaning that they evaluated the consequences of actions in terms of their expected effects upon happiness. Mill (1863, ch. 1) argued, "Whatever can be proved to be good, must be so by being shown to be a means to something admitted to be good without proof". However, Popper (1966) argued that striving to maximize happiness is a 
Lisbeth M. BREVIK. Research Ethics: An Investigation into Why School Leaders Agree or Refuse to Participate in Educational Research

PROBLEMS

OF EDUCATION

IN THE $21^{\text {st }}$ CENTURY Volume 52, 2013

10

the consequences of one's actions. Popper (1966) therefore suggested replacing the utilitarian formula 'maximize happiness' with the formula 'minimize suffering'. He argued that promoting happiness is far less urgent than preventing suffering or pain.

School leaders might use utilitarianism as a tool for ethical reasoning when choosing whether to participate or not based on their evaluation of the consequences. However, according to Mill (1863) and Bentham (1789, 2005), participation or non-participation must then be a means to something admittedly good without needing direct proof. The art of education is proved to be good by its production of knowledge, but how is it possible to prove that knowledge is good? School leaders might give their consent if participation contributes to providing a better education for their students, or related to Popper (1966) they might withhold their consent if it involves extra work for the teachers, that is to say if extra work is considered inherently negative. They might also consider the intensity and duration of participation, the relevance of the research project for the school and how many people it would affect (teachers, students). The leaders would then choose the alternative with the greatest positive value for the school, or the least negative one if none of the alternatives are positive. According to utilitarianism, good intentions are not sufficient for a school to participate in a research project. The outcome must involve the common good for the school; otherwise, the school leaders might use consequence ethics as a reason to refuse participation. Ideally, if a school leader chooses to participate for utilitarian reasons, it does not mean it is the best choice only for him or her, but that it is best for everyone. That is to say, the interests of each individual receive equal weight to balance competing interests against each other. Obviously, this depends on the decision to participate or not being properly considered as maximizing happiness or minimizing suffering.

A critical perspective on consequence ethics is therefore the notion of individualism versus collectivism. What if a school leader argues that participation would be positive for the school in terms of professional development, but involves too much work for teachers in terms of time and effort? For example, how many positive consequences would participation need to have for a school in order to make a teacher's extra work on the project worthwhile?

In contrast to consequence ethics, duty-based ethics recognizes that some actions are inherently good or wrong. In Kant's Groundwork for the Metaphysics of Morals (1785), he argued that morality is not based on the principle of utility, but on human reason. He proposed the categorical imperative, a rule that is true in all situations or contexts. The first version of the categorical imperative says, "Act only on that maxim whereby thou canst at the same time will that it should become a universal law" (Kant, 1785). This suggests that a person has a duty to choose his or her actions based on universal laws of right or wrong. This implies that any moral judgement must be applicable to every identical situation; if the action cannot be universally adopted, it is morally wrong. Based on this universalizability of the categorical imperative, it would be wrong to break a promise. A school leader's withdrawal of consent to participate in a research project would then be morally wrong according to Kantian ethics, regardless of the reasons s/he might present, ethical or otherwise.

The second version of the categorical imperative emphasizes the importance of treating people as valuable: "Act so that you treat humanity, both in your own person and in that of another, always as an end and never merely as a means." (Kant, 1785). According to this second version, a school leader's decision to participate should be based on consideration for the people concerned: the teachers and the students. This further applies to the researchers in that they should consider all participants in research as valuable and not as a means to obtain research data.

In Norway, educational researchers are obliged to take subjects' self-image seriously (NESH, 2006). Even though participants officially can withdraw their consent at any time, they might consider the Kantian principle of keeping a promise to override their right to withdraw their consent. This principle suggests that the school leader cannot simply consent to participate in a research project if participation involves the teachers, without regard to the teachers' wishes or needs, even if it might involve breaking a promise. 
To sum up, these two meta-ethical positions consider individual acts, judging them either by their consequences (cost/harm or benefit) or according to whether they satisfy certain universal principles (duty or rights). The two meta-ethical positions correspond to what Paine (1994) refers to as integrity-based ethics and compliance-based ethics. Integrity-based ethics stimulates contextualised considerations of the right way to act, for example, based on the consequences or effects of an action. Compliance-based ethics, on the other hand, stimulates uniform standards that should be applied in all situations, like duty-based ethics. Clearly, there are other meta-ethical positions as well, and clearly, various forms of ethical reasoning are likely to be observed, depending on how these meta-ethical approaches are interpreted (Hammersley, 2009). In the following section, I will explore how ethical reasoning may play a role when ethical concerns arise in specific situations where schools are invited into a research project. Situational characteristics might affect ethical reasoning among school leaders. This in turn can help researchers develop a better understanding of potential participants' decisions with regard to accepting or declining to participate.

\section{Methodology of Research}

\section{General Background of Research and the Researcher's Role}

Against this background of ethical theories, the main purpose of this study was to provide a description of the reasons for accepting or refusing to participate that appeared in emails from Norwegian secondary school leaders who were invited to participate in the research project. The project involves the collection of secondary data from a national mapping test of reading for upper secondary school students. The test is administered through the Norwegian Directorate for Education and Training (UDIR) and is mandatory for all pupils in their first year at the upper secondary school (approximately 60,000 students). After the students have taken the mapping test, their teachers correct the tests based on a national guide provided by UDIR and the test results are reported as three sum scores for each student. The project was approved by UDIR, and they granted me permission to collect the test results from the schools (secondary data), provided that each school gave consent. The intention was to collect the test results in order to analyse the students' reading skills. The school leaders were provided with what was believed to be relevant information about the project and what participation entailed. In the process of recruitment, while hoping for consent, it was equally relevant to see what reasons the school leaders gave regarding their decision to participate or not.

Within utilitarianism, consequences might be considered in terms of cost and benefit. From this perspective the costs for the schools were (1) to fill in the students' test results in an electronic form (excel) instead of the paper-based form provided by UDIR, and to e-mail the excel file to me; (2) to substitute the students' names with a student ID provided by UDIR. Related to Bentham's and Mill's utilitarianism, participation implies the responsibility as a researcher to avoid an asymmetrical relation where there is no promise of reward for the participating schools. In order to balance the costs, the participating schools were offered two potential benefits: (1) they would receive an analysis of the results regarding their students; (2) the teachers at the participating schools would be invited to an in-service course about reading, based on the analysis and intended as professional development.

\section{Sample}

This is a population study covering all upper-secondary schools in Norway (349 schools situated in 19 counties). County administration and principals at all the upper-secondary schools were asked whether their schools would be interested in participating in the study. They were contacted in two steps. Step 1: The education director in each of the 19 counties was contacted 
Lisbeth M. BREVIK. Research Ethics: An Investigation into Why School Leaders Agree or Refuse to Participate in Educational Research

PROBLEMS

OF EDUCATION

IN THE $21^{\text {st }}$ CENTURY Volume 52, 2013

by phone and information about the project was sent by e-mail. All directors accepted the invitation and sent a letter to the school principals, recommending participation in the project. Step 2: Then each principal was contacted by e-mail, providing information about the project. The correspondence was with school principals or a person assigned by them, in this paper referred to as the school leaders. A total of 236 schools responded to the invitation (68\%) while 113 schools did not respond (32\%). The school leaders at the 236 responding schools either accepted or refused participation by e-mail. This is illustrated in Table 1 below.

Table 1. The responding schools: 194 accepted participation and 42 refused. $\mathbf{N}=236$.

\begin{tabular}{lcccc}
\hline Responding schools & Yes & No & Total & $\%$ \\
\hline Gave reason & 49 & 14 & 63 & 27 \\
No reason & 145 & 28 & 173 & 73 \\
\hline Total & 194 & 42 & 236 & 100 \\
\hline
\end{tabular}

Table 1 summarizes information about the answers provided from the 236 responding schools; 173 of these schools did not give any reasons (73\%). They responded by saying merely that they would like to - or not like to - participate in the project. Sixty-three schools gave reasons for their choice to participate or not (27\%). Consequently, the 63 school leaders who provided reasons are the informants in this paper; 49 of these accepted participation, while 14 of them refused. Since my project concerns secondary sources, it comprises data (test scores) that have already been produced (mandatory mapping test). In other words, the students are not the respondents in this project, at least not in the sense of providing consent, since the schools provide me with their students' test results. In this paper, the data consists of the answers from schools that were asked to participate in my project by providing the test results. Therefore, there are no respondents, but rather informants and the data comprise the informants' answers. The 63 schools that gave reasons belong to all 19 counties in Norway. They are both rural schools and city schools of various sizes and some offer general studies while others offer vocational studies. In other words, there is nothing particular about the schools who gave reasons compared to those who did not. Nevertheless, due to the sample size there will be no claim to generalizability. However, the informants still provide interesting information that should be useful regarding the schools' perspectives related to research projects.

\section{Procedure}

In order to perform the analysis of the informants' e-mail responses, the amount of data was reduced in a three-stage procedure. In the first stage, the e-mails saying that they would consider the request and return with an answer were removed. In the second stage, all e-mails that only included answers simply responding "yes" or "no" to participation were removed. In the third stage, longer answers without explicit reasons were removed, such as: "We would like to participate in the project", "Your project sounds interesting, count us in", or "Unfortunately we cannot participate in your project". The final data set consisted of the 63 reasons.

The resulting data set was used to develop a coding scheme based on the research questions: (1) what reasons do school leaders give for participating or not participating? (2) Do they argue from the perspective of the students, the teachers, or the school? (3) How explicit are their answers in terms of ethical reasoning? In order to develop the coding scheme, the data were considered using a combination of meaning condensation and meaning categorisation (Kvale, 1996). In practice, all the answers were read through several times, to get an impression of how the school leaders reasoned and to identify the natural meaning units of the emails. During this initial analysis, a coding scheme was developed based on the reasons given; 
whether the school leaders referred to the school, the teachers or the students in their answers and whether the reasons could be understood ethically. The categories were chosen to reflect the naturally occurring reasons rather than a pre-defined set of reasons. The coding scheme is provided in Appendix A.

\section{Analysis of E-mail Data}

The reasons were divided into those who accepted participation and those who refused. Then the 63 reasons were coded with the coding scheme in Appendix A developed to capture the school leaders' naturally occurring reasoning along three main categories: (1) considering individuals, groups or the organization; (2) considering the explicitness in light of consequence ethics; (3) considering the explicitness in light of duty ethics. The first main category was subdivided into students, teachers and school. The second main category was divided into the subcategories area of priority, professional development, time and effort, student competition and adapted education. The third main category consisted of one subcategory only: keeping promises. The distinction between these types of reasoning corresponds with the ethical theories of consequence (Bentham, 1789, 2005; Mill, 1863) and duty (Kant, 1785). First, each reason was coded, using the coding scheme described above. Then the coding process was repeated after two months, and the data were reanalysed. There was a satisfactory overlap in the results, both concerning comparisons of the reasons that were identified, and the coding of reasons into categories.

\section{Results of Research}

\section{Naturally Occurring Reasons}

The school leaders who agreed to participate had similar reasons for participating. They emphasised two main reasons: (1) the schools' areas of priority; (2) teachers' professional development. The school leaders reasoned as follows: (1) Area of priority: Many stated that they would like to participate because reading was an area of priority for their schools. They considered participation in the project according to a two-way perspective; by providing data, they would in return learn more about reading - an area they were going to focus on at the school independent of the project. When arguing specifically that this was an area of priority for schools, a typical response was, "On behalf of the principal I hereby confirm that our school wants to participate in your project about reading. It fits well with our plans to conduct a reading project this school year. Therefore, we are also interested in the course offered as a follow-up to the reading project. We look forward to cooperating with you!" (my translation). (2) Professional development: Although the school leaders regarded reading as an important area of priority for their schools, several of them mentioned professional development as the most salient reason for participation. They stated that they were interested in their teachers participating in an inservice reading course as suggested by the above quote. Some school leaders argued that this would also benefit students, who would in turn profit from their teachers acquiring new knowledge as part of their professional development. In fact, most of the reasons involved the idea that participation would provide the schools with an analysis of the test results, which in return might benefit their instructional methods.

With regard to those who did not want to participate, the range of reasons was more diverse even though there were only 14 schools. The various reasons have been divided into three main types: (1) time and effort; (2) student competition; (3) adapted education. In their answers, the school leaders reasoned as follows: (1) Time and effort: Most of the non-participants' reasons involved their schools' lack of capacity to participate, and some said that it involves too much work for the teachers. This is a typical response provided by one of the school leaders: "We do not have the capacity to participate in this project. It entails too much work" (my trans- 
Lisbeth M. BREVIK. Research Ethics: An Investigation into Why School Leaders Agree or Refuse to Participate in Educational Research

PROBLEMS

OF EDUCATION

IN THE $21^{\text {st }}$ CENTURY Volume 52,2013

14 lation). Three schools withdrew from the project after initially having agreed to participate. They explained that this was because they realised they were involved in too much work, but that they were sorry to withdraw since they had already promised to participate. (2) Student competition: Two school leaders refuse participation because they feared the negative consequence of competition amongst the students. They fear that students would be more concerned with their reading score than how the results might be used to improve their reading skills. This is a response from one of the schools: "The teachers [...] feel that they cannot participate due to the aspect of competition that it represents for the students" (my translation). (3) Adapted education: Seven school leaders said their students did not take the mapping test, even though it is mandatory. They argued that results from the test provided too little information about their students' reading skills. Three of them said that their students were to participate in a different reading test, which they argued provided them with useful information in order to improving their students' reading skills. This is a representative explanation from one of these schools:

For the last four years, we have used [a different test] instead of the mapping test from Udir. We find [the other test] better in many ways, not least because it is electronic, as opposed to Udir's paper version. Through using this test, we have developed good routines to follow up with each student, enabling us to give adapted learning to all students [...]. As known, Udir's mapping test is not to be reported to anyone, as opposed to national tests, where we obviously would comply. The county director has, by the way, bought the license to [the other test] that we use. Udir's mapping tests only provide information about the students [with reading skills] below a critical limit, while we, as mentioned, experience that [the other test] is a lot better as a pedagogical tool. [...] Based on this situation it is difficult for us to participate in your project (Author`s translation).

These naturally occurring reasons provide information about the school leaders' considerations. In the next section, the perspectives presented in these reasons will be considered.

\section{The Perspectives Presented}

The school leaders' answers reveal that there were minimal differences in the perspectives presented of those who agreed to participate and those who refused. Twenty-four percent of those who consented to participate presented the students' point of view as the main reason. Interestingly, the same was found among those who refused to participate; $24 \%$ of them also argued from the point of view of the students. Further, $36 \%$ of those who agreed to participate said they did so based on the point of view of the teachers, as did $35 \%$ of those who refused to participate. Finally, the main point of view leaders considered in their rationale was that of the school as an organization; this was argued by $40 \%$ of the participants and by $41 \%$ of the nonparticipants.

As indicated by the findings above, the naturally occurring reasons present various perspectives within the school as an organization. In the next section, these results will be discussed in the light of ethical reasoning.

\section{Discussion}

In this study, the following main research question is considered: What reasons do school leaders give when agreeing or refusing to participate in educational research? The following subsidiary questions are also addressed:

(1) What reasons do school leaders give for participating or not participating?

(2) Do they argue from the perspective of the students, the teachers or the school?

(3) How explicit are their answers in terms of ethical reasoning?

A core ethical concern in the findings is that in their reasoning, the school leaders seem 
to consider the consequences of participation more than the acts themselves (providing test results). This approach goes back to Mill $(1863)$ and Bentham $(1789,2005)$ and seeks to understand ethics in terms of the consequences imposed on a person. Bentham $(1789,2005)$ claimed that good acts lead to happiness; that the joy of doing the right thing benefits the greater good. In this study, school leaders' reasons suggest that they explicitly or implicitly use ethical reasoning related to consequence ethics when considering participation and that an ethical conflict might arise if a school leader is uncertain whether participation might result in the greater good for the students, the teachers or the school. This approach also relates to integrity-based ethics (Paine, 1994), centred on asking the following question: What is the right way to act? Consequently, when school leaders' provide reasons for whether or not they want to participate in a research project, they seem to apply consequence ethics, or integrity-based ethics, especially from the perspective of the school and the teachers, but also to some extent from the perspective of the students.

Based on the data presented in this study, it would seem that a researcher who wants to ensure a high response rate should take care to balance costs and benefits for the participating schools, ensuring a symmetrical relationship between the researcher and the schools. A utilitarian might argue that the negative consequences of investing teachers' time and effort should be weighed against the positive consequences of professional development. School leaders tend to give varying priority to these concerns and adopt different compromises among them (Hammersley, 2009). However, as researchers we need to respect their reasoning (Grave \& Walsh, 1998).

\section{Explicitness of Ethical Reasoning}

The school leaders' reasoning can be understood in light of the theory of consequence ethics. When participating schools argue that a project relates to their area of priority, this could be understood as an explicit consideration that the consequences of participating provide greater common good than not participating. The schools provide results and consequently get help analysing the results, which they in turn can use within their prioritised area, for the greater good of the school, their teachers and potentially their students. At the same time, they contribute to the project, which benefits researchers. The school leaders' reasoning could also be understood in terms of accountability; if schools are measured on their areas of priority, participation might be used as a leadership tool related to accountability (Elstad, Christophersen \& Turmo, 2012; Propper \& Wilson, 2003). If their area of priority is reading; participating in a research project about reading could provide positive accountability measures in terms of contributing to professional development in the area, or possibly by increasing test scores for future students. Similarly, when participating schools argue that they accept participation because it might contribute to their professional development, it can be understood with regard to consequence ethics as well. The potential consequences of participating in a particular project are that teachers get information about reading that might contribute to their professional development and they can participate in an in-service reading course. All the participating schools in the present study have suggested this as an important reason for participation; both those who argued that reading was an area of priority for them, and those who argued that they were positive to the professional development participation might provide for their teachers. In the light of consequence ethics, participation contributes to the greater good for schools, according to the school leaders' reasoning mentioned here.

Interestingly, non-participating school leaders' reasoning can also be understood within the framework of consequence ethics. When they argued that the schools and the teachers lack the capacity to participate, they explicitly said that the consequences of participating would be that the school and the teachers spent time and effort in providing me with the test results - time they do not have. This suggests that the school leaders in this study will not sacrifice the interests of teachers even if they do acknowledge that their schools could benefit from participating.

$\mid \begin{aligned} & \text { PROBLEMS } \\ & \text { OF EDUCATION } \\ & \text { IN THE 21 } 1^{\text {st }} \text { CENTURY } \\ & \text { Volume 52, } 2013\end{aligned}$ 
Lisbeth M. BREVIK. Research Ethics: An Investigation into Why School Leaders Agree or Refuse to Participate in Educational Research

PROBLEMS

OF EDUCATION

IN THE $21^{\text {st }}$ CENTURY Volume 52, 2013

16

The school leaders seemed to regard teachers' wishes or needs. Further, when the school leaders argued that their students would not take the test; their reasoning can be related to the utilitarian principles of consequence ethics. This suggests that these school leaders regard test participation as not beneficial for the students. The aspect of potential competition amongst students by participating in the project also relates to the potential of being ranked as a school across all participating schools. The school leaders consider the consequences of such ranking as negative and not participating as having more positive outcomes for their students or the school. The school leaders' reasons can also be understood as providing protection for schools in an age of accountability (Elstad, Christophersen \& Turmo, 2012; Propper \& Wilson, 2003). The consequences of participation would be too great; non-participation would have more benefits than participation.

The three schools that first agreed to participate and later withdrew from participation gave reasons that can also be understood within Kantian duty ethics. When they withdrew their consent, they explicitly said that they were sorry because they had previously promised to participate. This could be characterized as duty ethics, even though the reasons were not explicitly identified as such by the school leaders.

The analysis of the explicitness of ethical reasoning shows that the answers from all 63 school leaders who gave reasons for their participation or non-participation can be understood within the theory of consequence ethics, and that three of the school leaders' reasons can also be understood within the theory of duty ethics. Nevertheless, based on the school leaders' overall descriptions of their reasons, their ethical reasoning did not seem to be a salient feature at the schools. A possible exception was the leaders of the seven schools who admitted that they did not participate in the mandatory mapping test. However, because their reasons were based on their students' perspective and they can be understood as consequence ethics, this may be an ethical act nevertheless.

The reasons for participating or refusing to participate suggest ethical considerations regarding the right way to act, which is particularly relevant since these ethics are not applied in 'black and white' situations, but instead to the grey areas where different values are at stake (Nijhof, Wilderom \& Oost, 2012). Even in situations where a promise was broken, the school leaders chose to withdraw from participating in the project based on the negative consequences of participation. Their reasons suggest that they try to balance and apply different values in their own very concrete grey-area school contexts. The values that underpin their everyday practices may have ethical implications for the school leaders' reasons for accepting or refusing to participate.

\section{School Leaders' Values}

Although no school leaders used the specific term 'values', certain values are implied based on their responses. What is and is not considered ethically acceptable depends upon the context, and certain values might relate to the school context of providing test results. The school leaders' reasoning suggests that the following four value judgments are relevant:

Respecting autonomy. It would seem that many of the school leaders used a cost/benefit analysis in their reasoning about whether or not to participate in the proposed project. This relates to showing respect by taking teachers' time seriously and considering what is the best use of their time. School leaders seem to have used the measurement of time and effort to quantify the positive consequences of participation, which is expected given the various demands on teachers' work load. Thus in many cases when a school faces a decision that has identifiable effects on the teachers' work load, a cost/benefit analysis is required. The effects of participation are identified and their impact on the teachers is calculated. When these costs and benefits are added up and the outcome is negative, non-participation is seen to be beneficial. The value of time is also evident when the school leaders argue that the mapping test is not beneficial for their students. They suggest that time spent on the test will lead to negative 
consequences for the students - time better spent on other educational tasks. This complies

PROBLEMS

OF EDUCATION

IN THE $21^{\text {st }}$ CENTURY

Volume 52,2013 with two value principles Hammersley and Traianou (2012a) propose: respecting autonomy and treating people equitably, in the sense that both students and teachers are respected so that neither students nor teachers are unjustly involved in a research project.

Valuing competence. Within educational research, school leaders might use the framework of consequence ethics if they accept or refuse participation based on a promised reward or lack of reward. This can be understood as what Hammersley and Traianou (2012a) refer to as the extrinsic value principle of offering reciprocity, where researchers offer something in return for participation: something that the informants can reasonably expect, and that will contribute to a symmetrical relationship between the researcher and the informants. The return or reward in this study is professional development (competence) promised to all participating schools, in addition to an analysis of school results. This potential reward might contribute to increased knowledge for the school, their teachers and their students about the school's area of priority, i.e. reading. Such knowledge might they used to improve reading instruction or as a tool in adapted education. This suggests that the school leaders considered competence to be of such great value that this is their main reason for participating in my project.

Protecting privacy. Refusing participation due to a potential competition between students suggests that protecting students is considered a value judgement. This line of reasoning is regularly used when national test results are used by the media to rank schools or place students in categories. To a certain extent, this can be understood as what Hammersley and Traianou (2012a, 2012b) refer to as the extrinsic value principles of protecting privacy and minimising harm for those involved and others as well. An ethical conflict might arise if a school leader believes that participation would result in the loss of anonymity as a result of media attention.

Keeping promises. Kant's categorical imperative (1785) and Paine's compliance-based ethics (1994) capture the reasons given by the three school leaders when they withdrew their consent after initially consenting to participate. Their reasons relate to the universal law of keeping promises and we can conclude from the categorical imperative that breaking a promise is wrong. The following answer from one of the school leaders illustrates this: "Unfortunately, we must withdraw our consent to participate in this project. We are very sorry. We hope this will not place you in a difficult situation." (my translation). The school leader explained that they were unable to carry out the necessary work and provide the results for the project due to 23 new teachers and two new school leaders starting at the school. Even though the value of keeping a promise is evident, they seem to regard the consequences of time and effort as having greater value.

To sum up, what is and is not ethically acceptable for school leaders regarding their participation in this research project seemed to be decided by the grey zones of the school context. The utilitarian values of respecting the school's accountability measures and the teachers' time and competence override the values of keeping promises in the manner argued by Kant (1785).

\section{Conclusions and Implications}

In the present study upper secondary school leaders' willingness to participate in a research projects was investigated, or to be more exact, the reasons school leaders give when agreeing or refusing to participate in educational research. This addresses one of the greatest challenges educational researchers face, ensuring a high response rate. This means getting past the deluge of information school leaders receive every day.

For the school leaders in this study, the ethical upside of research participation seems particularly clear from a utilitarian perspective. If the consequences of participation are positive, then they chose to participate; if the consequences of participation are negative, they refused to do so. It also shows that, ultimately, the value judgment for participation or non-participation 
Lisbeth M. BREVIK. Research Ethics: An Investigation into Why School Leaders Agree or Refuse to Participate in Educational Research

PROBLEMS

OF EDUCATION

IN THE $21^{\text {st }}$ CENTURY

Volume 52, 2013

18 lies with the school leader. A further implication is that by learning about the informants' reasons for participating, or not participating in a project, researchers can in their invitations better provide the information needed to help their informants to make well-informed decisions. However, in the present study, several school leaders did not respond, and this is certainly one area where further research should be initiated to learn why certain schools do not respond.

The findings in this study raise another dilemma. Even though the informants apply utilitarian ethics, the researcher might apply Kantian ethical conduct. The second variant of Kant's categorical imperative says that you should "act in regard to every rational being (thyself and others), that he may always have place in thy maxim as an end in himself" (1789). This suggests that it is the researcher's responsibility is also to ensure a symmetrical relationship - one where the participants also profit from participating in the research project - and do not merely serve as a means of providing data.

\section{References}

Bentham, J. (1789, 2005). An Introduction to the Principles of Morals and Legislation. Oxford: The Clarendon Press. The 1789 version retrieved 1/03/2013, from http://www.econlib.org/library/ Bentham/bnthPML.html

Busher, H., \& James, N. (2012). The Ethical Framework of Research Practice. In: A. Briggs, M. Coleman, \& M. Morrison (Eds.), Research Methods in Educational Leadership \& Management, $3^{\text {rd }}$ Ed. London: SAGE Publications, Ltd.

Cook, T. D., \& Campbell, D. T. (1979). Quasi-experimentation: Design and analysis issues for field settings. Boston, MA: Houghton Mifflin Company.

Creswell, J. W. (2013). Qualitative Inquiry \& Research Design. Choosing Among Five Approaches, $3^{\text {rd }}$ Ed. USA: SAGE Publications, Inc.

Elstad, E., Christophersen, K-A., \& Turmo, A. (2012). The strength of accountability and teachers' organisational citizenship behaviour. Journal of Educational Administration, 50 (5), 612 - 628.

Fowler, F. J. (2009). Survey Research Methods, $4^{\text {th }}$ Ed. Thousand Oaks, CA: Sage Publications, Inc.

Grave, M. E., \& Walsh, D. J. (1998). Studying children in context: Theories, methods and ethics. Thousand Oaks, CA: Sage Publications, Inc.

Hammersley, M. (2009). Against the ethicists: on the evils of ethical regulation. International Journal of Social Research Methodology, 12 (3), 211-225. Retrieved 1/03/2013, from http://www.tandfonline.com/doi/abs/10.1080/13645570802170288

Hammersley, M., \& Traianou, A. (2012a). Ethics and Educational Research. British Educational Research Association on-line resource. Retrieved 23/02/2013, from http://www.google.no/url?sa=t\&rct=j\&q $=\&$ esrc $=\mathrm{s} \&$ source $=$ web $\& \mathrm{~cd}=1 \& v e d=0 \mathrm{CC} 0 \mathrm{QFjAA} \&$ url $=\mathrm{http} \% 3 \mathrm{~A} \% 2 \mathrm{~F} \% 2 \mathrm{Fwww} \cdot$ bera $\cdot \mathrm{ac} \cdot \mathrm{uk} \% 2 \mathrm{~F}$ system $\% 2$ Ffiles\%2FEthics\%2520and\%2520Educational\%2520Research.pdf\&ei=H90oUZH_K 43HsgaYyoGoCg\&usg=AFQjCNFDMDq65vqXmQ3_JIbYG7cWl_bjEg\&bvm=bv.42768644,d. Yms.

Hammersley, M., \& Traianou, A. (2012b). Ethics in Qualitative Research. Controversies and Contexts. London: SAGE Publications Ltd.

Heath, S., Charles, V., Crow, G., \& Wiles, R. (2004). Informed consent, gatekeepers and go-betweens. Paper presented to stream on 'The Ethics \& Social Relations of Research' Sixth International Conference on Social Science Methodology: Amsterdam, August 2004. Retrieved 23/02/2013, from http:/www.google.no/url?sa=t\&rct=j\&q=\&esrc=s\&source=web\&cd=2\&ved=0CDUQFjA B\&url=http $\% 3 \mathrm{~A} \% 2 \mathrm{~F} \% 2 \mathrm{Fwww}$. sociology.soton.ac.uk\%2FProj\%2FInformed_Consent\%2FISA.r tf\&ei=bZIoUZbwIoPatAaq14CADA\&usg=AFQjCNGkG25eAcpS1gyWwDxmb0WuNaQPgg\& bvm=bv.42768644,d.Yms.

Hesse-Biber, S. N., \& Leavy, P. (2011). The Practice of Qualitative Research, $2^{\text {nd }}$ Ed. USA: SAGE Publications, Inc.

Homan, R. (2001). The Principle of Assumed Consent: The Ethics of Gatekeeping. The Journal of the Philosophy of Education Society of Great Britain, 35 (3), 329-343.

Kant, I. (1785). Groundwork for the Metaphysics of Morals. Hutchinson. Retrieved 1/03/2013 from http://www.justiceharvard.org/resources/immanuel-kant-groundwork-for-the-metaphysics-ofmorals-1785/ 
Lisbeth M. BREVIK. Research Ethics: An Investigation into Why School Leaders Agree or Refuse to Participate in Educational Research

Kvale, S. (1996). Interviews: An introduction to qualitative research interviewing. Thousand Oaks, CA: Sage Publications, Inc.

Mill, J. S. (1863). Utilitarianism. Retrieved 24/02/2013, from http://www.utilitarianism.com/mill1.htm and http://www.utilitarianism.com/mill2.htm

NESH (National Committee for Research Ethics in the Social Sciences and the Humanities in Norway) (2006). Guidelines for research ethics in the social sciences, law and the humanities. Oslo: NESH. Retrieved 3/02/2013, from www.etikk.no.

Nijhof, A., Wilderom, C., \& Oost, M. (2012). Professional and institutional morality: building ethics programmes on the dual loyalty of academic professionals. Ethics and Education, 7 (1), 91-109.

Nuremberg Code (1947). Retrieved 2/03/2003, from http://www.jewishvirtuallibrary.org/jsource/Holocaust/Nuremberg_Code.html

Paine, L. S. (1994). Managing for organizational integrity. Harvard Business Review, 72, 106-117.

Popper, K. (1966). The Open Society And Its Enemies. Complete: Volumes I and II, $5^{\text {th }}$ Ed. Retrieved 28/02/2013, from http://www.inf.fu-berlin.de/lehre/WS06/pmo/eng/Popper-OpenSociety.pdf

Propper, C., \& Wilson, D. (2003). The use and usefulness of performance measures in the public sector. Oxford Review of Economic Policy, 19, 250-267.

Ragin, C., \& Amoroso, L. M. (2011). Constructing Social Research. The Unity and Diversity of Method, $2^{\text {nd }}$ Ed. USA: SAGE Publications, Inc.

Ryen, A. (2011). Ethics and Qualitative Research. In: Silverman, D., Qualitative Research, $3^{\text {rd }}$ Ed. London: SAGE Publications, Ltd, 416-438.

Silverman, D. (2011). Qualitative Research, $3^{\text {rd }}$ Ed. London: SAGE Publications, Ltd.

Vestøl, J. M. (2005). Relasjon og norm i etikkdidaktikken. Moralsk/etisk verktøybruk i spennet mellom elevtekster og fagdidaktiske fremstillinger. PhD Thesis, Faculty of Educational Sciences. Oslo: University of Oslo.

West, H. R. (2013). Utilitarianism. The International Encyclopedia of Ethics. Retrieved 24/02/2013, from http://onlinelibrary.wiley.com/doi/10.1002/9781444367072.wbiee178/abstract?deniedAccessCus tomisedMessage $=\&$ userIs Authenticated $=$ false.

\section{Appendix A}

Coding scheme, including subcategories within three main categories. The categories resulted from an analysis of the naturally occurring reasons for participation and non-participation provided by the school leaders.

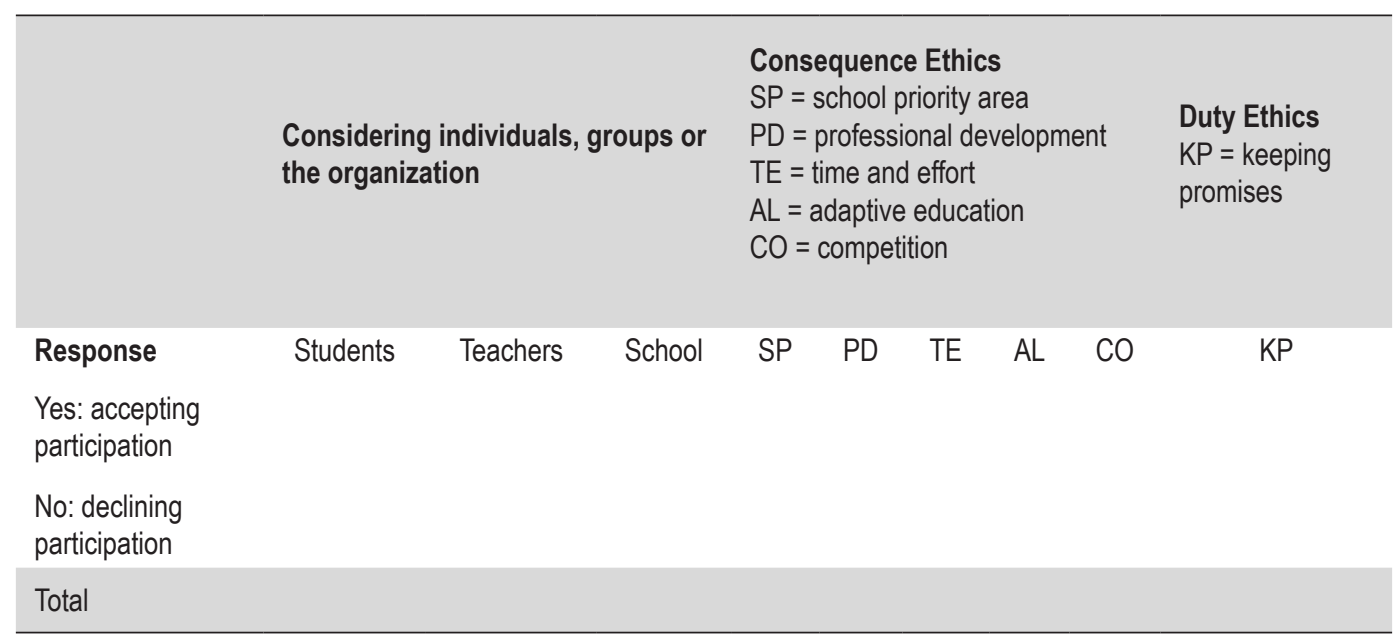


Lisbeth M. BREVIK. Research Ethics: An Investigation into Why School Leaders Agree or Refuse to Participate in Educational Research

PROBLEMS

OF EDUCATION

IN THE $21^{\text {st }}$ CENTURY

Volume 52, 2013
Advised by Laima Railiené, University of Siauliai, Lithuania

Accepted: March 18, 2013

Received: January 28, 2013

Lisbeth M. Brevik Master of Philosophy in British and American Literature, PhD Candidate, University of Oslo, Department of Teacher Education and School Research, P O Box 1099 Blindern, 0317 Oslo, Norway.

E-mail: I.m.brevik@ils.uio.no

Website: http://www.uv.uio.no/ils/personer/vit/lisbbr/index.html 